\title{
Analysis of the Efficiency Level of Sharia Rural Financing Bank (SRFB ) Using Data Envelopment Analysis (DEA)
}

\author{
Leyla Mariana ${ }^{1}$ and Harun ${ }^{2}$ \\ ${ }^{1}$ Faculty of Islamic Studies, Universitas Muhammadiyah \\ Surakarta \\ email: leylamariana220@gmail.com \\ ${ }^{2}$ Faculty of Islamic Studies, Universitas Muhammadiyah \\ Surakarta \\ email: har179@ums.ac.id
}

\begin{abstract}
This research aims to analyze the efficiency level of Sharia Rural Financing Bank (SRFB) in Surakarta. This study used data from four Rural Sharia Banks taken from www.ojk.co.id, which published its annual report. This study conducted inputoutput variables with the Data Envelopment Analysis (DEA) method as a tool of analysis. The results of the research showed that the SRFB Dana Amanah is indicated as efficient during the 2017 period. The other three are indicated as inefficient in the last quarter. The inefficiency source came from its operational cost and its incapability to get higher output.
\end{abstract}

Keywords: Efficiency, Data Envelopment Analysis, Sharia Rural Financing Bank, analysis.

\section{INTRODUCTION}

Sharia Rural Financing Bank (SRFB) is a bank that conducts business activities based on sharia principles, which in its activities do not provide interest or usury in payment. An SRFB is a business entity and similar to a conventional credit bank in the form of a limited liability company or regional company (Jianti, 2015).

SRFB, as one of the institutions in the bank, has a financial intermediation function. According to Zammir \& Mirakhor 
(2008), the function of financial intermediation is the process of collecting or purchasing surplus funds from the business sector, government, and households, to be channeled to deficit economic units. In its financial activities, the SRFB facilitates this intermediation function by providing a contract or contract that is implemented following sharia provisions.

According to Sholahuddin \& Hakim (2018), SRFB can be interpreted as banks whose work system has implemented a sharia economic system based on Islamic sharia. SRFB was established in general and correctly to fill opportunities with conventional bank policies in setting interest rates and also various financial and monetary policy packages. Then SRFB is known as a system that adheres to the Islamic economic system based on Islamic Sharia principles.

SRFB in Surakarta has shown considerable development, as it can be seen from several aspects. Table 1 shows the number of SRFB offices and customer development in Surakarta from 2014 to 2018 .

Table 1. SRFB Office and Customer Data in Surakarta City in 2014-2018

\begin{tabular}{cccccc}
\hline SRFB & $\mathbf{2 0 1 4}$ & $\mathbf{2 0 1 5}$ & $\mathbf{2 0 1 6}$ & $\mathbf{2 0 1 7}$ & $\mathbf{2 0 1 8}$ \\
\hline Number of Offices & 5 & 5 & 5 & 6 & 6 \\
Number of Customers & 472 & 539 & 689 & 757 & 795 \\
\hline
\end{tabular}

Source: Financial Services Authority (data processed).

The table above illustrates the number of Sharia Rural Financing in Surakarta has increased from 2014-2018. Viewed from 2014, the number of offices that initially had five offices in 2018 increased to 6 offices. In 2014 the number of SRFB customers had reached 472 then escalated in 2018 to 795 customers. It can be concluded that Sharia Rural Finance Banks have excellent performance from year to year. In addition to the number of offices and customers, the ability of SRFB to generate profits can also be a benchmark for SRFB performance. Table 2 shows the increase in SRFB companies in generating profits. 
Journal of Islamic Economic Laws-January, Vol. 3, No. 1, 2020

Table 2. SRFB Profit in Surakarta City in 2014-2018

\begin{tabular}{lccc}
\hline \multicolumn{1}{c}{ SRB } & $\mathbf{2 0 1 6}$ & $\mathbf{2 0 1 7}$ & $\mathbf{2 0 1 8}$ \\
\hline Dana Mulia & $3,527,784$ & $4,436,354$ & $6,518,594$ \\
Trust Funds & $2,685,627$ & $4,228,446$ & $5,079,008$ \\
Central Syariah Utama & $2,366,937$ & $3,292,529$ & $4,399,636$ \\
Harta Insan Karimah & $9,683,034$ & $15,153,444$ & $21,011,920$ \\
Total & $18,263,382$ & $27,110,773$ & $37,009,158$ \\
\hline
\end{tabular}

Source: Financial Services Authority (data processed).

Table 2 shows the increase of SRFB profit in Surakarta within a period of 5 years from the year 2016 -2018. SRFB in Surakarta City was able to generate profits $18,263,382$ in 2016 and increased to 27,110,773 rupiahs in 2018. In 2018 SRFB profit became higher to $37,009,158$ rupiahs. This concluded that the SRFB in Surakarta shows a relatively rapid development and has an excellent performance from year to year.

The purpose of this study was to determine the level of efficiency of the Sharia Rural Financing Bank (SRFB) in Surakarta for the 2017 period and determine the steps that must be taken to improve performance. It is hoped that the Government and Bank Indonesia would use this research as an information tool and consideration for rural banking policy. In order to achieve national economic stability, SRFB efficiency needs to be improved. Besides, this paper is expected to be a guide for evaluating SRFB performance in Surakarta, so it can be taken into consideration to make corrective policies to improve the performance of Rural Banks. This research also can be used as reference material for future research discussing the efficiency of Sharia Rural Financing Bank.

\section{LITERATURE REVIEW}

\section{Definition of Islamic People's Financing Bank}

Banking Law No. 10 of 1998 stated that a Rural Bank is a bank financial institution that carries out its business activities conventionally or based on sharia principles (Darsono, 2003). BPR conducting activities based on sharia principles have obtained 
implementing regulations in the form of a letter from the Board of Directors of Bank Indonesia No. 32/36 / KEP / DIR concerning Rural Credit Banks Based on Sharia Principles dated May 12, 1999. In technical terms, Sharia Rural Banks can be interpreted as financial institutions as conventional SRFB whose operations use sharia principles (Darsono, 2003).

\section{Sharia Bank Financing Bank Businesses}

According to Darsono (2003), SRFB has several businesses to carry out its activities, including the following:

1. Collecting funds from the public in the form of deposits in the form of time deposits, savings, and or other forms.

2. Give credit.

3. Provide funding and placement of funds based on sharia principles under the provisions stipulated by Bank Indonesia.

4. Placing funds in the form of Bank Indonesia Certificates, time deposits, certificates of deposit, and or savings with other banks.

The forms of Sharia Rural Bank fund distribution to the public can be categorized below:

1. Wadiah Savings

In this savings, the bank accepts savings ( saving accounts ) from customers in the form of free savings. Whereas the bank binds the contract with the customer in the form of a wadiah. The deposit is not borne by the customer, and the bank provides a bonus to the customer. The bonus is obtained by the bank from profit sharing and credit financing activities to other customers. Wadiah savings bonuses can be calculated daily and paid to customers every month.

2. Mudharabah Savings

In mudarabah financing, banks enter into contracts with customers (entrepreneurs). The bank provides venture capital financing for projects managed by the company. Profits will be shared (profit-sharing agreement) by the agreement that has been bound by the bank and the entrepreneur. 
3. Murabahah receivables

In this murabahah account, the bank as the provider of funds to the customer to buy goods by confirming the purchase price to the buyer (customer) and the buyer (customer) pays it at a price more than the agreed profit of the Bank.

In addition to conducting business activities as referred to above, the Sharia Rural Bank may also act as a Baitul Mal institution, namely receiving funds from zakat, infaq, alms, endowments, grants or other social funds and channeling them to those entitled to in the form of compensation and or benevolent loans ( qardhul hasan )(Darsono, 2003).

\section{Definition of efficiency}

The concept of efficiency is fundamental and was born from the concept of economics. However, the concept of efficiency can be defined in various perspectives and backgrounds. In general, efficiency can be directed to the concept of achieving an outcome with optimal use of resources. According to (Karim) 2004, efficient is doing the things right, which means that doing everything in the right way to get optimal results.

In economic theory, there are two general concepts about efficiency, the efficiency in terms of economic concepts ( economic concept ), and efficiency in terms of the concept of production ( production concept). Efficiency, which is reviewed by the economic concept, has a broader scope, which is viewed from a macro perspective. In contrast, efficiency from a production point of view is viewed from a micro perspective (Sukirno, 2008).

\section{Measurement of Efficiency through Data Envelopment Analysis}

Frontier Approach, according to Silkman (1986) in Muhammad \& Puspitasari (2007), can be divided into two types, namely parametric and non-parametric frontier approaches (Muhammad \& Puspitasari, 2007).

Parametric tests are tests whose models specify certain conditions regarding population parameters that are the source of 
research. In contrast, non-parametric statistical tests are tests whose models do not specify conditions regarding population parameters that are the parent of the research sample. .The parametric frontier approach can be measured by parametric statistical tests such as the Stochastic Frontier Analysis (SFA) and Distribution Free Analysis (DFA) methods. While the non-parametric frontier approach can be measured by non-parametric statistical tests using the Data Envelopment Analysis (DEA) method.

\section{The Concept of Efficiency in Islamic Perspectives}

Islam strongly advocates efficiency, starting from financial efficiency, time, even in saying and doing the things that are in vain (no benefits and no badness) alone is ordered to leave it, let alone do something that contains evil or loss. Islamic Sharia is not only focused on regulating the way of worship but also pay attention to guide daily activities, including economic activities as well.

The concept is summarized in Islamic economics or Islamic economics, which regulates individuals in their muamalah. Islamic attention to dynamic behavior is strongly emphasized by Allah. Islam encourages people not to behave extravagantly, in this case, economic activity, because behaving luxury is classified as a devotee who was denied renounced to Allah.

The application of Islamic teachings in companies or financial institutions and SRFB can be measured by looking at the level of efficiency in the use of the existing input to generate the maximum output level without any wastage of resources (inputs) owned. Efficient in this case does not mean by reducing costs as low as possible to produce maximum output, so that legalizing all means and actions in achieving it (Puspitasari, 2017).

\section{Previous research}

Observing SRFB in Semarang City, Septianto \& Widiharih (2010) used Data Envelopment Analysis (DEA) and found that the Data Envelopment Analysis Method can provide a picture based on the relative efficiency value of a BPR unit compared to other SRFB in Semarang City so that SRFB can reorganize the 
operational conditions of SRFB in order to achieve even better performance. In his research, the intermediation approach is used, using input variables: capital, interest costs, and other operating costs, and the output variables include: loan credit income and other operating income.

Yahya (2012) used Data Envelopment Analysis (DEA) found that SRFB in Central Java in the 2005-2010 period experienced an average efficiency of $95.19 \%$, and no one-year span spans the optimal efficiency of $100 \%$. In his research, an intermediation approach was used, using input variables, including iB savings, iB deposits, and paid-in capital. At the same time, the output variables included placements with other banks, mudarabah, murabahah, ijarah, and qard.

Nugroho (2016) observed 2 SRFB in Surakarta using Data Envelopment Analysis (DEA) and found the result that SRFB in Surakarta that operated efficiently during 2015 there were 2 SRFB, where the efficiency values were 1.00 each. In his research, the intermediation approach used wadiah savings, mudarabah savings, and mudarabah deposits as input variables, and placements with other banks, receivables, and financing as output variables.

Ramadhan (2017) found that the output variables on the SRFB in 2016 were, on average efficient. However, there were several SRFB units that had to increase their output variables to reach the most efficient point. In his research, the intermediation approach is used by using input variables, including wadiah savings, mudarabah savings, and personnel expenses. In contrast, the output variables include placements with other banks and mudarabah receivables.

\section{METHODS}

\section{Analysis Tools and Models}

The analytical tool used in this study is DEA (Data Envelopment Analysis). DEA is a procedure specifically designed to measure the relative efficiency of an organizational unit called the DMU (Decision Making Unit) that uses several inputs and output variables, where the combination of inputs and outputs is 
not possible. The relative efficiency of a DMU is the efficiency of a DMU compared to other DMUs in the sample (a group of comparable DMUs) that use the same type of input and output.

According to Septianto \& Widiharih (2010), the DEA model as a device to measure performance efficiency has at least three advantages compared to other models, such as multiple linear regression models. Advantages from DEA model can measure input and output variables, and not require assuming a functional relationship between the variables measured, and can have different measurement units.

The relative efficiency values range from 0 to 1 or 0 to $100 \%$. A DMU has the best ability if the relative efficiency value is 1 or $100 \%$. In contrast, another DMU whose value is below $100 \%$, then the ability is still below the DMU that has been efficient (Septianto \& Widiharih, 2010).

There are two types of Data Envelopment Analysis (DEA) models. The model that was first introduced was the DEA Constant Return To Scale (CRS) model or seen from the inventor's name also known as the Charnes, Cooper, and Rhodes (CCR) model and the second model was the DEA Variable Returns to Scale (VRS) model or commonly referred to as also the Barnes, Charnes, and Cooper (BCC) models according to their inventor's name. This study used DEA Constant Return To Scale (CRS) method.

DEA identifies efficient DMUs and is used as a benchmark for inefficient DMU repairs. The DEA also makes it possible to calculate the amount needed to improve input and output in the DMU so that it becomes efficient.

\section{Efficiency Analysis}

The concept of efficiency used in this study refers to technical efficiency ( Technical Efficiency), namely the ability of a company to obtain maximum output from the use of input. The frontier production function is a production function that describes the maximum output that can be achieved from each level of input use. If a company is at a point in the frontier production function, it means that the company is technically efficient. If the frontier production function is known, then technical inefficiency can be 
estimated by comparing the actual position relative to the frontier.

\section{Definition of Input and Output Variable}

To determine the efficiency of the Intermediary Function of the SRFB requires input and output variables. Input and output variables in this study are:

1. Input Variable:

a. Wadiah saving is a customer deposit that must be maintained and returned at any time when the customer concerned wants it, with a unit of measurement of thousands of rupiah (Karim, 2004).

b. Mudarabah Savings is a fund that is saved as a form of investment because the customer gets a profit (ratio/ profit share), the unit of measure is thousands of rupiah (Karim, 2004).

c. Personnel Expenses are funds incurred by SRFB to pay employees, with a unit of measurement of thousands of rupiah (Ramadhan, 2017).

2. Output Variable:

a. Fund placements in other banks are bank deposits held by other banks to support the smooth operation of operations, with a unit of measurement of thousands of rupiah (Nugroho, 2016).

b. Murabahah receivables are bills arising from the transaction between banks and customers, with a unit of measurement of thousands of rupiah (Nugroho, 2016).

\section{Data source}

The type of data used in this study is secondary data. The data is collected from the balance sheet, income statement, and other information of each SFRB in Surakarta. The data is obtained from government agencies and website official Financial Services Authority (FSA) www.ojk.go.id. Also, the data obtained is supported by reading various sources, including journals, books and other scientific paper related to banking efficiency 


\section{RESULTS AND DISCUSSION}

\section{Development of Islamic People's Financing Banks in Indonesia}

The development of SRFB in Indonesia is always experiencing growth every year. The number of SRFB in Indonesia in 2017 grew to 167 Units.

For Central Java Province, the number of SRFB in 2017 is banks. In this study, the data used 4 SRFB in Surakarta and would be measured its efficiency by using Data Envelopment Analysis (DEA).

\section{Analysis of Input and Output Variables Used in Research}

This study compared the efficiency of the Syari'ah People's Financing Bank (SRB) as a calculation using the Data Envelopment Analysis (DEA) analysis method. In this study using three inputs and two outputs.

The input variables are wadiah savings, mudarabah savings, and personnel expenses, while the output variable used is placement in other banks, and murabahah receivables. The first variable in this study is Wadiah's savings. The development of Syari'ah People's Financing Banks (Sharia Rural Banks) is shown in the table below.

Table 4.5 Tabungan Wadia $h$ (in rupiah)

\begin{tabular}{ccccc}
\hline $\mathbf{2 0 1 7}$ & Dana & SRB DM & CSU SRB & SRB HIK \\
\hline March & $1,785,072$ & $1,206,143$ & $1,793,324$ & $5,770,910$ \\
June & $1,713,055$ & $1,684,424$ & $1,636,097$ & $6,100,344$ \\
September & $2,382,421$ & $1,160,843$ & $1,846,296$ & $7,402,574$ \\
December & $2,424,255$ & $1,790,879$ & $1,909,748$ & $7,731,655$ \\
amount & $8,304,803$ & $5,842,289$ & $7,185,465$ & $27,005,483$ \\
\hline
\end{tabular}

Source: Financial Services Authority (data processed).

Based on Table 4.5 shows that there is an increase in wadiah savings, there is a decrease every month. Of the four Syari'ah People Financing Banks (SRFB) used as research samples, SRFB Harta Insan Karimah has the highest value with a total of 27,005,483 ( SRFB HIK ), while SRFB Dana Mulia which has the lowest value with a total of 5,842,289 ( SRFB DM ). 
The second variable in this study is mudarabah savings. The development of Syari'ah People's Financing Banks (Sharia Rural Banks) is shown in the table below.

Table 3. Mudarabah Savings (in rupiah)

\begin{tabular}{ccccc}
\hline $\mathbf{2 0 1 7}$ & Dana Amanah & Dana Mulia & CSU SRB & SRB HIK \\
\hline March & 24,936 & $9,409,166$ & 786,417 & $1,119,395$ \\
June & 32,497 & $10,616,349$ & 182,060 & $1,138,101$ \\
September & 21,388 & $13,115,141$ & 176,907 & $1,383,648$ \\
December & 24,463 & $12,098,257$ & 197,327 & $1,515,893$ \\
Total & 103,311 & $45,238,913$ & $1,342,711$ & $5,157,037$ \\
\hline
\end{tabular}

Source: Financial Services Authority (data processed).

Based on Table 3, the data shows that there is an increase in mudarabah savings, and there is a decrease every month. Of the four Syari'ah People Financing Banks (SRFB) used as research samples, SRFB Dana Mulia has the highest value, with a total of 45,238,913 (SRFB DM ). In contrast, SRFB Dana Amanah has the lowest value, with a total of 103,311 ( SRFB DA ).

The third variable in this study is the personnel burden. The development of Syari'ah People's Financing Banks (Sharia Rural Banks) is shown in the table below.

Table 4. Personnel Expenses (in rupiah)

\begin{tabular}{ccccc}
\hline 2017 & SRFB DA & SRB DM & CSU SRB & SRB HIK \\
\hline March & 242,704 & 219,870 & 267,094 & 955,388 \\
June & 527,354 & 449,165 & 581,913 & $1,929,834$ \\
September & 757,316 & 693,238 & 875,455 & $2,861,838$ \\
December & 985,724 & 952.147 & $1,164,178$ & $3,714,759$ \\
amount & $2,513,098$ & $2,314,420$ & $2,888,640$ & $9,461,819$ \\
\hline
\end{tabular}

Source: Financial Services Authority (data processed).

Based on Table 4 shows that the burden of personnel has increased every month. Of the four Syari'ah People Financing Banks (SRFB) used as research samples, SRFB Harta Insan Karimah has the highest value, with a total of 
9,461,819 (SRFB HIK ), while SRFB Dana Mulia which has the lowest value with a total of 2,314,420 ( SRFB DM ). Output variables are placements with other banks and murabahah receivables. The first output variable in this study is placed in another bank. The development of SRFB (Sharia Rural Financing Banks) is shown in the table below.

Table 5. Placements with Other Banks (in rupiah)

\begin{tabular}{lcccc}
\hline \multicolumn{1}{c}{ 2017 } & SRFB DA & SRB DM & CSU SRB & SRB HIK \\
\hline March & $3,465,549$ & $1,681,640$ & $2,806,377$ & $6,153,909$ \\
June & $1,949,325$ & $3,123,000$ & $1,903,178$ & $9,490,571$ \\
September & $4,561,295$ & $6,030,699$ & $3,454,997$ & $9,033,301$ \\
December & $5,266,229$ & $3,645,929$ & $3,699,329$ & $14,119,983$ \\
amount & $15,242,398$ & $14,481,268$ & $11,863,881$ & $38,797,764$ \\
\hline
\end{tabular}

Source: Financial Services Authority (data processed).

Based on table 5, it is shown that placements with other banks have increased, while there have been decreases every month. Of the four Sharia Rural Financing Banks (SRFB) which were used as research samples, SRFB Harta Insan Karimah had the highest value with a total of 38,797,764 ( SRFB HIK ), while the SRFB Central Syariah Utama which had the lowest value with a total of $11,863,881$ ( SRB CSU ). The second output variable in this study is murabahah receivables. The development of SRFB is shown in the table below.

Table 6. Murabahah receivables (in rupiah)

\begin{tabular}{lcccc}
\hline \multicolumn{1}{c}{$\mathbf{2 0 1 7}$} & SRFB DA & SRB DM & CSU SRB & SRB HIK \\
\hline March & $12,154,203$ & $15,599,883$ & $8,909,149$ & $44,366,894$ \\
June & $13,117,453$ & $16,382,838$ & $9,286,253$ & $52,668,599$ \\
September & $13,390,137$ & $16,352,066$ & $10,742,434$ & $54,961,250$ \\
December & $15,302,237$ & $16,962,245$ & $13,228,803$ & $57,847,929$ \\
Total & $53,964,030$ & $65,297,032$ & $42,166,639$ & $209,844,672$ \\
\hline
\end{tabular}

Source: Financial Services Authority (data processed). 
Based on table 6 shows that murabahah receivables have increased every month. Of the four Syari'ah People's Financing Banks (SRFB), which were used as research samples, SRFB Harta Insan Karimah had the highest value with some 209,844,672 ( SRFB HIK ), while the SRFB Central Syaria'ah Utama which had the lowest value with a total of 42,166,639 ( SRB CSU ).

\section{Analysis of SRFB Efficiency in Surakarta City Based on Data Envelopment Analysis (DEA)}

In this study, the DEA analysis with output orientation will be analyzed, so if there is an SRB that is not significant, the output will be increased. Overall, efficient and inefficient SRBs can be seen in table 7.

Table 7. Results of Calculation of SRFB Efficiency

Quarter I-IV in the 2017 period

\begin{tabular}{ccccc}
\hline SRB & Quarter I & Quarter II & Quarter III & Quarter IV \\
\hline DA & 1,000 (efficient) & 1,000 (efficient) & 1,000 (efficient) & 1,000 (efficient) \\
DM & 1,000 (efficient) & 1,000 (efficient) & 1,000 (efficient) & 0,770 (inefficient) \\
CSU & 0,770 ( inefficient) & 0,604 ( inefficient) & 0,877 ( inefficient) & 0,975 ( inefficient) \\
HIK & 1,000 (efficient) & 1,000 (efficient) & 0,860 (inefficient) & 0,974 ( inefficient) \\
\hline
\end{tabular}

Source: DEAP data processing results 2.1

Table 7 shows the value of each SRFB units. Based on this result, it can be seen that in the first Quarter of 2017, there are 3 SRFB that have been efficient, namely SRFB Dana Amanah, SRFB Dana Mulia, and SRFB Harta Insan Karimah. While SRFB that experience inefficiency are SRFB Central Syari'ah Utama $(0,770)$.

In the second quarter of 2017, there were 3 SRFB that was already efficient, namely SRFB Dana Amanah, SRFB Dana Mulia, SRFB Harta Insan Karimah. While SRFB that experience inefficiency are SRFB Centra 1 Syari'ah Utama $(0,604)$. In the third quarter of 2017, there were 2 SRFB that had been efficient, namely SRFB Dana Amanah and SRFB Dana Mulia. While SRFB that experience inefficiencies are SRFB Centra Syari'ah Utama $(0,877)$ and SRFB Harta Insan Karimah (0,860). In Quarter IV 
of 2017, there was only 1 SRFB that had been efficient, namely SRFB Dana Amanah, while the three SRFB that experienced inefficiencies were BPR Dana Mulia $(0,770)$, SRFB Centra Syari'ah Utama $(0,975)$, and SRFB Harta Insan Karimah $(0,974)$.

\section{Inefficiency Analysis and Improvement}

From the 4 SRFB that became the object of research in the 2017 period, there will be an analysis of the sources of inefficiency that occurred in Quarter IV. The following can be seen in the level ofBPR S inefficiency based on each input and output, as well as the causes.

\section{SRFB Dana Mulia Quarter IV}

In Quarter I V 2017, SRFB Dana Mulia experienced an inefficiency with TE 0.770 . The scenarios for achieving efficiency from SRFB Dana Mulia can be seen in table 8.

Table 8. Value of Original Value and Projected Value of SRFB Dana

Mulia

Quarter I V

\begin{tabular}{lcccc}
\hline & Original Value & $\begin{array}{c}\text { Radial } \\
\text { Movement }\end{array}$ & $\begin{array}{c}\text { Slack } \\
\text { Movement }\end{array}$ & $\begin{array}{c}\text { Projected } \\
\text { Value }\end{array}$ \\
\hline & Quarter I, the efficiency level is $\mathbf{0 . 7 7 0}$ & \\
\hline $\begin{array}{l}\text { Placements with } \\
\begin{array}{l}\text { Other Banks } \\
\text { Murabahah } \\
\text { receivables }\end{array}\end{array}$ & 3645929,000 & 1087150,226 & 0,000 & 4733079,226 \\
$\begin{array}{l}\text { Wadiah Savings } \\
\text { Mudharabah }\end{array}$ & 16962245,000 & 5057835,325 & 0,000 & 22020080,325 \\
$\begin{array}{l}\text { Savings } \\
\text { Personnel Burden }\end{array}$ & 12098257,000 & 0,000 & 0,000 & 12098257,000 \\
\hline
\end{tabular}

Source: DEAP data processing results 2.1

The table illustrates that to achieve the conditions of efficiency. The SRFB Dana Mulia should raise output placements with other banks that previously 3645929,000 (in rupiah) to 1087150,226 (in rupiah), and the output of Murabahah receivables previously 16962245,000 (in rupiah), must be raised to 5057835,325 (in rupiah). This because there is a slack condition; the personnel 
expenses input must be reduced by 362998,606 (in rupiah) from 952147,000 (in rupiah) to 589148,394 (in rupiah).

\section{SRFB Central Syariah Utama Quarter IV}

In Quarter I V 2017, SRFB Central Syariah Utama experienced an inefficiency with TE 0,975 . The scenarios for achieving efficiency from the SRFB Central Syari'ah Utama can be seen in Table 9.

Table 9. Value of Original Value and Projected Value of SRFB Central Syari'ah Utama

Quarter IV

\begin{tabular}{lccrr}
\hline & \multicolumn{1}{l}{$\begin{array}{l}\text { Original } \\
\text { Value }\end{array}$} & \multicolumn{1}{l}{$\begin{array}{l}\text { Radial } \\
\text { Movement }\end{array}$} & $\begin{array}{l}\text { Slack } \\
\text { Movement }\end{array}$ & Projected Value \\
\hline \multicolumn{4}{c}{ Quarter I, the level of efficiency is 0.975} \\
\hline $\begin{array}{l}\text { Placements with } \\
\text { Other Banks }\end{array}$ & 3699329,000 & 96335,321 & 0,000 & 3795664,321 \\
$\begin{array}{l}\text { Murabahah } \\
\text { receivables }\end{array}$ & 13228803,000 & 344495,173 & 0,000 & 13573298,173 \\
$\begin{array}{l}\text { Wadiah Savings } \\
\text { Mudharabah }\end{array}$ & 1909748,000 & 0,000 & 0,000 & 1909748,000 \\
$\begin{array}{l}\text { Savings } \\
\text { Personnel Burden }\end{array}$ & 197327,000 & 0,000 & 0,000 & 197327,000 \\
\hline
\end{tabular}

Source: DEAP data processing results 2.1

Table 9 depicts that in order to achieve efficient conditions, the SRFB Central Syari'ah Utama must increase the output of placements with other banks which were previously 3699329,000 (in rupiah) to 96335,321 (in rupiah), and the output of murabahah receivables which were previously 13228803,000 (in rupiah), must be increased 3444495,173 (in rupiah).

This because there is a slack condition that causes personnel expense input must be reduced by 447321,954 (in rupiah) from 1164178,000 (in rupiah) to 716856,046 (in rupiah). 


\section{SRB Harta Insan Karimah Quarter IV}

In Quarter I V 2017, SRFB Harta Insan Karimah Utama experienced an inefficiency with TE 0,974. The scenarios for achieving efficiency from the SRFB Central Syari'ah Utama can be seen in table 10 .

Table 10. Value of Original Value and Projected Value of SRFB Harta Insan Karimah Quarter IV

\begin{tabular}{|c|c|c|c|c|}
\hline & Original Value & $\begin{array}{l}\text { Radial } \\
\text { Movement }\end{array}$ & $\begin{array}{l}\text { Slack } \\
\text { Movement }\end{array}$ & Projected Value \\
\hline \multicolumn{5}{|c|}{ Quarter I, the level of efficiency is 0.974} \\
\hline $\begin{array}{l}\text { Placements with } \\
\text { Other Banks }\end{array}$ & 14119983,000 & 375366,002 & 0,000 & 14495349,002 \\
\hline $\begin{array}{l}\text { Murabahah } \\
\text { receivables }\end{array}$ & 57847929,000 & 1537830,877 & 0,000 & 59385759,877 \\
\hline Wadiah Savings & 7731655,000 & 0,000 & 0,000 & 7731655,000 \\
\hline $\begin{array}{l}\text { Mudarabah } \\
\text { Savings }\end{array}$ & $15,15893,000$ & 0,000 & 0,000 & $15,15893,000$ \\
\hline Personnel Burden & 3714759,000 & 0,000 & 988697,447 & 2726061,553 \\
\hline
\end{tabular}

Source: DEAP data processing results 2.1

Table 10 shows that to achieve the conditions of efficient, and then the SFRB Harta Insan Karimah should raise output placements with other banks that previously 14119983,000 (in rupiah) into 375366,002 (in rupiah), and the output of murabahah receivables previously 57847929,000 (in rupiah), should be raised 1537830,877 (in rupiah). Because of a slack condition, the personnel expense input must be reduced amount 988697,447 (in rupiah) from 3714759,000 (in rupiah) to 2726061,553 (in rupiah).

\section{CONCLUSION}

Based on the data analysis, only the SRFB Dana Amanah Ummah is efficient for the full year. While the other 3 SRFB, there were inefficiencies in the last quarter of 2017. Sources of inefficiency from the three SRFB were sourced from the suboptimal output or results that included placement of cash in other banks and murabahah receivables. Also, the source of 
inefficiency is caused by personnel expenses and mudarabah savings funds, which need to be reduced.

This study provides suggestions for inefficient SRBs to be able to make improvements to the input and output variables that cause inefficiency, such as by reducing the burden on personnel. This research is limited to many SRFB in the Surakarta region and is expected to be able to increase the number of SRFB examined in subsequent studies.

\section{REFERENCES}

Darsono, H. (2003). Bank dan Lembaga Keuangan Syariah: Deskripsi dan Ilustrasi. Jakarta: Raja Grafindo Persada.

Jianti, L. G. (2015). Efisiensi Bank Umum Syariah dan Bank Pembiayaan Rakyat Syariah. Universitas Negeri Semarang.

Karim, A. (2004). Bank Islam (Analisis Fiqih dan Keuangan). Jakarta: Raja Grafindo Persada.

Muhammad, H., \& Puspitasari, R. (2007). Analisis Perbandingan Efisiensi Bank Syariah di Indonesia Dengan Metode Data Envelopment Analysis Periode 2005. Jurnal Ekonomi Dan Bisnis Islam, 2(3), 86-88.

Nugroho, T. A. (2016). Analisis Efisiensi Bank Pembiayaan Rakyat Syariah (BPRS) di Surakarta menggunakan Data Envelopment Analysis (DEA) Periode 2016. Universitas Muhammadiyah Surakarta.

Puspitasari, A. (2017). Analisis Efisiensi Bank Umum Syari'ah Di Indonesia dengan Metode Data Evelopment Analysis (DEA). (Studi Pada BUSN Devisa Bank Umum Syari'ahPeriode 2014-2015). Universitas Muhammadiyah Surakarta.

Ramadhan, A. (2017). Analisis Efisiensi Bank Pembiayaan Rakyat Syariah (BPRS) di Surakarta menggunakan Data Envelopment Analysis (DEA) Periode 2017. Universitas Muhammadiyah Surakarta.

Septianto, H., \& Widiharih, T. (2010). Analisis Efisiensi Bank Perkreditan Rakyat di Kota Semarang dengan Pendekatan Data Envelopment Analysis. Jurnal Ekonomi Dan Bisnis, 
$3(1), 42-45$.

Sholahuddin, M., \& Hakim, L. (2018). Lembaga Ekonomi dan Keuangan Syariah. Universitas Muhammadiyah Surakarta.

Sukirno, S. (2008). Makro Ekonomi Teori Pengantar. Jakarta: PT Raja Grafindo Jakarta.

Yahya, M. (2012). Menakar Efisiensi BPRS Sebagai Bank Pembiayaan Rakyat Berbasis Bagi Hasil. Jurnal Ekonomi Dan Keuangan., 80(1), 60-63.

Zammir, I., \& Mirakhor, A. (2008). Pengantar Keuangan Islam: Teori dan Praktik. Jurnal Ekonomi Islam, 4(2), 11-12. 